\title{
THE SOCIAL DIMENSION OF THE INTERNET FROM THE PERSPECTIVE OF PEOPLE WITH DISABILITIES DURING THE COVID-19 PANDEMIC
}

\begin{abstract}
For many people, not only those with disabilities, the Internet during the Covid-19 epidemic has become a living space in which they can fulfil their social needs throughout the obligatory social isolation. Previous studies show that social networking sites have great potential to build and strengthen social relations, creating a space that allows people with disabilities to participate in the debate on topics that are important to this social category and to fight for their rights. They also stimulate the formation of a sense of community, which builds a unique bond and solidarity among people with disabilities. In this sense, they constitute an important space that is conducive to shaping their identity. The main goal of the article is to show the relationship between the use of social media and the elements that constitute the identity of people with disabilities and to show the social activities and roles assumed in the Internet space. Three hundred and forty-six people, who followed Facebook's groups for people with disabilities participated in the online survey.
\end{abstract}

Keywords: disability identity, social media, virtual community, Covid-19 pandemic, social relations

Dr, Faculty of Humanities; e-mail: zuchowska@agh.edu.pl; https://orcid.org/0000-0002-8198-9900 


\section{INTRODUCTION}

Based on data from Social Diagnosis in 2015, which studied 3210 people with disabilities in 2015, 37.7 \% had access to the Internet. This compares to 54.5\% of non-disabled people who had access [Diagnoza Społeczna Baza 2015]. It is evident that social media are very popular among people with disabilities. For example, $50.9 \%$ of respondents declared they had a Facebook account, $41 \%$ had other social media accounts, and $36.3 \%$ used forums and discussion groups [Czapliński, Panek 2015: 249-250], indicating the great importance of social media for people with disabilities in modern Poland. This trend has continued since 2013 [see Masłyk, Migaczewska, Stojkow, Żuchowska-Skiba 2016: 74]. It is particularly important today because during the Covid-19 pandemic, a large part of society's activity, including that of people with disabilities, has moved to the Internet [see Zaagsma, Volkers, Swart, Schippers, Van Hove 2020; Walsh, Cormack, MacLachlan 2020].

The Internet enabled the creation of an "online space" in which users can interact with others and build virtual communities within social networking sites [see Henderson, Henderson, Bowley 2010]. Social media allow people with disabilities to participate widely in cultural, social and political activities, allowing them to participate more in social life [Ellis, Goggin 2015; Goggin 2015]. The social dimension of the Internet is understood here as the implementation of functions through interactions with other users, where these interactions can be undertaken with many people simultaneously in the same place.

In this context, it is important to examine the relationship between the social dimension of the Internet and the roles undertaken online, self-esteem, and the ways of defining disability. This will allow us to recreate the essential elements that make up the identities of people with disabilities who use social networking sites [see Darling, Heckert 2010a].

\section{THE IDENTITY OF PEOPLE WITH DISABILITIES}

The second half of the 20th century brought about a change in the position of people with disabilities. It was connected with the emergence of movements that promoted minority rights and increased activity among people with disabilities, who began to claim their rights and fight for inclusion in society on equal terms [Thomas 2004: 571]. A change in the disability definition model also occurred at this time, and these processes influenced a change of identity in the environment of people with disabilities [Gill 1997: 40; Darling 2003]. According to Tom 
Shakespeare [1996], the identity of people with disabilities is largely determined by the way 'disability' is defined in medical or social terms.

The medical approach recognised negative identity as a result of disability. Social attitudes, on the other hand, viewed negative self-identification as a result of experiencing oppressive social relations, and focused on the possibilities of changing society, empowering disabled people and promoting a new self-image that would foster positive identities among people with disabilities [Shakespeare 1996]. The rejection of the prevailing recognition of disability in individual categories as personal tragedy made it possible to replace the negative identity of people with disabilities with the feeling of pride in who they are, and affirmative identity based on the belief that disabled people are capable of living actively, happily and independently in society [Swain, French 2000: 578; French, Swain 2012: 22-23]. Thus, the adoption of a new way of defining disability was an important factor for changes to occur in identity among people with disabilities.

Research on the formation of identity of people with disabilities indicated that a vital role in changing the previous negative identity of people with disabilities and replacing it with a new - affirming disability - was played by a sense of belonging to a specific community of people with disabilities (communal attachments), and self-image [Hahn, Belt 2004]. Research on the identity dynamics of people with disabilities conducted by Carol Gill [1997] also showed that a sense of belonging to a community of people with disabilities is a crucial aspect that contributes to the formation of positive identities among this social category.

Similarly, Dunn and Burcaw [2013] demonstrated the relationship between identity and self-image participation in the community of people with disability and solidarity with this community. Meanwhile, Forber-Pratt and Zape [2017], when examining the identity of people with disabilities, indicated that acceptance of their own disability, a sense of immersion in the culture of disability and their involvement in this environment influence their shape. In her analysis of the identity of people with disabilities, Putnam [2005] showed the importance of political factors for changing negative identity to positive in this environment. In the proposed model, she pointed out six factors that affect the identities formed by people with disabilities: self-esteem, the unique pride of disability (being proud of who you are), the perceived level of discrimination, a sense of belonging to a community of people with disabilities, the approach to defining disability in social categories, and involvement in political activities for the benefit of the environment of people with disabilities.

It shows that political activities influence the formed identities that aim to promote a positive social change for people who share this identity [see Britt, 
Heise 2000; Stryker 2000]. Analyses conducted in Poland also indicate that people with disabilities who engage in this type of activity construct identities that are not negative and are aimed at changing the perception of disability by disabled people themselves and the whole of society [Stojkow, Żuchowska-Skiba 2014; Żuchowska-Skiba 2018]. This aspect is also emphasised by Darling and Hackert as being important for shaping positive identities. In their opinion, orientation towards disability - which combines the image of oneself as a person with a disability (disability identity), sharing a medical or social disability model, the level of participation in society, and taking action for one's own environment - plays a role in the identity of people with disabilities [Darling and Hackert 2010a; 2010b].

The multiplicity of ways of depicting the identity of people with disabilities shows that these depictions are a result of social situations and arise as part of the relationships in which individuals participate, in the form of internalised expectations of roles [Stryker, Burke 2000]. This points to the processual nature of the identity of people with disabilities and shows that these ways can change under the influence of a change of meanings that are related to it [Burke 2006: 81].

From this perspective, changes in behaviour can lead to identity changes, which can affect the social structure by redefining meanings related to the social role. It aims to innovate in the role using modern technology to achieve everyday, education, work etc. [Burke 2009: 124]. New media technologies mean that our understanding of the body, dependence/independence, ability and welfare now take on a new dimension, affecting shaped identities, which also change under the influence of technology [Goggin, Newell 2006].

Previous research shows that Internet technologies impact the processes of building and changing the identity of people with disabilities [Lupton, Seymour 2000]. Using social media allows them to build online identities that may differ from those imposed on them in the real world [Shpigelman, Gill 2014; Gustavsson, Nyberg 2015: 47; Bowker, Tuffin 2002, 2003] Thoreau 2006]. The Internet and new media enable people with disabilities to be independent in carrying out activities which are important factors that affect the formation of identity, thus empowering them [Ellis, Kent 2011: 54]. In addition, social media, as demonstrated by research, also strengthen the sense of subjectivity of people with disabilities by offering them the chance to join virtual communities, discussion groups in accordance with their own interests and needs [Goggin, Newell 2003:132]. Participating in them allows those in need to find support [Kamper, Goreczny 2007; Morris 2001; Goggin, Newell 2003: 131-132]. It also provides a sense of community, by offering them the opportunity to get 
involved in communities that bring together people with similar problems and experiences [Wright, Bell 2003]. It gives the feeling of being a part of a larger cultural group, which reduces feelings of isolation or alienation [Braithwaite et al., 1999, Poppen, Bradley 2003].

Social media are also a space for debate about the situation of people with disabilities in this community and the fight for their rights [Johnson, Moxon 1998: 255]. This is very important because the research shows that although the use of social media is not a factor that is conducive to integration with society in a cultural and social dimension, it does stimulate building a sense of belonging to communities among people with disabilities [Żuchowska-Skiba 2018]. The feeling of belonging fosters emotional attachment and promotes the expansion of the individual personality to take into account attributes, loyalty and obedience to groups [Guibernau 2013: 28]. Social media play an important role in this area. They are conducive to building a sense of belonging to a community of people with similar experiences, and they contribute to the mobilisation and strengthening of participation in political and public activities by people with disabilities. [Morris 2001; Seymour, Lupton 2004; Żuchowska-Skiba 2018]. This contributes to identity changes in people with disability because it allows them to move away from perceiving disability as a problem of the individual and to see its social context.

Social media enable people with disabilities to express their views and protest against discrimination and all forms of unequal treatment in society. An important element related to the presence of people with disabilities in the Internet space is the possibility of people with disabilities building images of disability and addressing issues they consider important. This enables them to show disability in a new light that was not present in traditional media [Thoreau 2006]. As a result, new media that require a different course of action become a field in which people with disabilities can achieve important role components to build a new identity and change social meanings and expectations about the role of a person with a disability in society [Burke 2009: 124]

\section{METHODOLOGY}

The primary goal of the study was to reconstruct the identities of people with disabilities who were active on social media. It was decided to adopt purposeful sampling. In September and October of 2020, I followed six accounts and five groups on Facebook, which brought together people with disabilities. I searched for profiles and groups using the search engine built into Facebook. I informed 
the administrator of the group/account about my desire to join due to the research. Only once was I refused. It allowed me to see people who are active both when creating their own posts and commenting on and replying to those of other users in the groups. Then I sent a link to people who published at least one post a week or commented on the post from September to October, asking them to fill in a survey.

The survey covered people who had had an account at least for two months and who published content on it at least once a week. It was decided to use a questionnaire, which was sent by email after obtaining the consent of the respondents to carry it out. The research was conducted in November and December 2020. Five hundred questionnaires were sent, which resulted in 346 returns, which were analysed.

In this approach, the identity of people with disability was characterised in relation to the use of social networks.

The identity of people with disabilities is built by four elements, with four corresponding parts of the study: The first part of the study investigated the relation between social media activity and the level of participation of respondents in "online life". It asked about the impact of social media activity on cultural activities (online cinema, theatre, museums) and social activities. Questions were asked about feelings of being lonely, respected and accepted.

The second group of questions was aimed at determining the relation between Internet use and the self-esteem of people with disabilities. It included questions showing how the respondents perceived their disability and what coping strategies they adopted. The aim was to determine the extent to which people with disabilities perceive their disability as a reason to feel pride or shame. The respondents were asked to determine the extent to which they agreed with the following statements: "Disability does not define me as a human being"; "I am proud of my disability"; "I expect acceptance of my otherness"; "My disability is an important part of who I am"; "I try to hide my disability whenever I can"; "My goal is to adapt to society". The respondents were also asked if they had a sense of influence on their own lives, whether it depended on them, on institutions and other people, or on God or fate.

The third group of questions was aimed at determining the relation between Internet use and the adopted model of defining disability (social versus medical). The respondents were asked to determine the extent to which they agreed with the following statements: "All buildings should be accessible to people with disabilities"; "Disability is not an individual problem, but a social one"; "Physical and cultural barriers are the reason for excluding people with 
disabilities"; "Doctors and other medical professionals know what is best for people with disabilities"; "People with disabilities require special schools and sheltered jobs to be created"; and "People with disabilities should be surrounded by compassion and charity support". This allowed us to reconstruct whether the respondents subscribed to the social model or the medical model of defining disability.

The fourth group of questions related to showing the relation between activity on social media and the roles that people with disabilities took up in the environment of people with disabilities. The respondents were asked to indicate activities they undertake for the benefit of people with disabilities. They included activities aimed at collecting funds, taking and giving advice, and fighting for the rights of people with disabilities. Later, they were asked about educational, social and economic activities undertaken in the network

The last part of the study was aimed at collecting the respondents' demographic and social data. In this part, I also asked about the average time they use the Internet (apart from study and work) and whether it had increased during the epidemic.

\section{STUDY RESULTS}

The study involved 346 people, of whom $46 \%$ were people with movement disabilities, $11 \%$ had visual disabilities, $12 \%$ had hearing disabilities, $20 \%$ had multiple disabilities, and $11 \%$ declared a different type of disability. The sample was dominated by women (59\%). The largest age category was that of $25-34$ year-olds ( $47 \%$ ), followed by $0-24$ years of age (39\%), and over 45 years of age (14\%). Nine per cent of the respondents had primary and lower secondary education, $59 \%$ secondary education (of whom $21 \%$ were still studying), and $48 \%$ post-secondary and higher education. Among those who completed the survey, $42 \%$ lived in a medium-sized city, $17 \%$ in the countryside, $11 \%$ in a small city, and 30\% in large cities. All respondents used Facebook; in addition, 22\% used YouTube, $12 \%$ Instagram, and $26 \%$ were active on Internet forums. This shows that Facebook was the most popular website among people with disabilities, with $49 \%$ of respondents using only this medium and engaging in an average of two groups.

All respondents declared that they used the Internet outside of study and work before the epidemic. Sixty-three per cent used it between 4 and 5 hours a week, 21\% - between 3 and 4 hours, 11\% - between 5 and 6 hours, 2\% - over 6 hours, and $4 \%-$ less than 3 hours. During the epidemic, all respondents noti- 
ced that their time online had increased. Seventy-three per cent used the Internet two hours more per week, $11 \%$ - three hours more per week, $13 \%$ - one hour more per week, $2 \%$ - more than three hours per week, and $1 \%$ - less than an hour longer a week. This shows that Internet use time has increased during the epidemic and lockdown.

In this context, it becomes important to ascertain how Internet use was related to the well-being of people with disabilities, their online activities, self-esteem, and how they define and perceive disabilities and the roles they take. These elements make up the identity of people with disabilities and formed the basis for the Questionnaire on Disability Identity and Opportunity (QDIO) [see Darling, Heckert 2010a]. As I was researching people with disabilities during the epidemic, I modified the questionnaire to include activities and roles taken virtually in online social networks.

To reconstruct the relationship between the use of social media and how people with disabilities perceive themselves and their disability, what roles and activities they take, and how they define disability [see Darling, Hackert 2010a], I used the Pearson correlation coefficient. It made it possible to show the strength of variable relationships, which were important elements that make up the identity of people with disabilities.

TABLE 1. Correlation between using social media and the activity and well-being of people with disabilities

\begin{tabular}{|l|c|}
\hline \multirow{2}{*}{ Activity and well-being of people with disabilities } & Using social media \\
\cline { 2 - 2 } & Pearson's $r$ \\
\hline Cultural activity online & 0.004 \\
\hline $\begin{array}{l}\text { Social activity online (keep in touch with family, } \\
\text { friends and other people and meet new people online) }\end{array}$ & 0.211 \\
\hline I feel lonely & -0.327 \\
\hline I feel accepted and respected & 0.601 \\
\hline
\end{tabular}

Source: Results of own studies. $\mathrm{N}=346$. The respondents answered yes/no/don't know to the questions. The answer "I don't know" was not taken into account in the analysis.

The collected data show that activity on social media does not affect cultural activity. In the social dimension, the use of social media also did not affect the participation of people with disabilities in social activities (see Table 1). This indicates that social media activity does not contribute to greater involvement in cultural and social activities. The use of social media contributed to the attenuating 
of the feeling of loneliness in people with disabilities. The analysis shows a weak inverse relationship between the use of social media (see Table 1) and the feeling of loneliness, which shows that the use of social media compensates for the lack of social contacts to a small extent and makes it possible to reduce the feeling of loneliness in this category. The data also show a medium-strong relationship (see Table 1) between the sense of being respected and accepted and the use of social media. This indicates that the use of social media has a positive effect on the quality of life of people with disabilities, partially eliminating the feeling of loneliness.

Analysing the data, it can be seen that activity on social media did not affect the feeling that the lives of people with disabilities depended on themselves (see Table 2). A weak relationship can be seen between the use of social media and the feeling that their lives depend on governmental, self-governmental and non-governmental institutions that are tasked with shaping policies toward people with disabilities and providing support and help to other people with disabilities. An average relationship can be seen between the feeling that the situation of people with disabilities depends on other people.

TABLE 2. Correlation between using social media and the sense of control over one's own life

\begin{tabular}{|l|c|}
\hline \multirow{2}{*}{ My life depends } & Using social media \\
\cline { 2 - 3 } & Pearson's $r$ \\
\hline on me & 0.101 \\
\hline on other people & 0.405 \\
\hline on institutions & 0.302 \\
\hline on God & 0.003 \\
\hline on fate & 0.002 \\
\hline
\end{tabular}

Source: Results of own studies. $\mathrm{N}=346$. The respondents answered yes/no/don't know to the questions. The answer "I don't know" was not taken into account in the analysis.

This shows that the use of social media does not affect the formation of self-deterministic attitudes; rather, it strengthens the feeling that the position of people with disabilities results from institutional and social conditions that, according to the respondents, determine their lives.

The subsequent questions were aimed at showing the relationship between the orientation of disability, which involves perceiving one's own physical, sensual or mental deficits in terms of stigma or pride, and the use of social media. This 
question was based on a 5-point scale ( 1 - completely disagree, 5 - completely agree) with statements that made it possible to reproduce the impact of perceiving one's disability on self-esteem and revealing the coping strategies adopted by the respondents. First, the average of the responses was calculated, and then, by combining the statements, two different disability orientations, pride vs shame, were created, and their Pearson correlation coefficient was calculated to show the strength of the relationship between disability orientation and the use of social media.

TABLE 3. Impact of using social media on disability orientation

\begin{tabular}{|c|l|c|c|c|}
\hline \multicolumn{2}{|c|}{ Average } & \multicolumn{2}{c|}{ Using social media } \\
\cline { 3 - 4 } \multicolumn{2}{|c|}{} & Standard deviation & Pearson's $r$ & \\
\hline \multirow{3}{*}{ pride } & Disability does not define me as a human & 4.4 & 1.0 & \multirow{2}{*}{0.417} \\
\cline { 2 - 4 } & I am proud of my disability & 2.4 & 1.1 & \\
\cline { 2 - 4 } & I expect acceptance of my otherness & 3.5 & 0.7 & \\
\hline \multirow{3}{*}{ shame } & I try to hide my disability whenever I can & 2.1 & 1.0 & \\
\cline { 2 - 4 } & My goal is to adapt to society & 1.2 & 0.6 & \multirow{2}{*}{0.221} \\
\cline { 2 - 4 } & $\begin{array}{l}\text { My disability is an important part } \\
\text { of who I am }\end{array}$ & 3.2 & 0.8 & \\
\hline
\end{tabular}

Source: Results of own studies. $\mathrm{N}=346$.

An average, strong correlation can be seen between the treatment of disability by the respondents in terms of pride. This is an important element showing that among people with disabilities who actively use the Internet, a positive identity is created, which involves appreciating their otherness and making it an asset, not a reason for shame. However, comparing the average answers to this question, it can be seen that for many respondents, disability is an important aspect of their identity, which means that they perceive themselves through the prism of their deficits, recognising that disability defines them. It was particularly present among hearing-impaired people, who most often chose this answer.

The question aimed at reproducing the respondents' preferred disability model was also based on assessing, on a 5-point scale (1 - completely disagree, 5 - completely agree), statements that made it possible to reproduce whether the respondents subscribe to the medical or social definition of disability. Therefore, first, the average response was calculated, and then two different models for defining disability, social versus medical, were created, and the Pearson correlation coefficient was calculated for them to show the strength of the relationship 
between the use of social media and the perceived disability model. It can be seen that there was a medium-strong relationship between the use of social media and the adoption of the social model of disability. However, when analysing the average of the answers to questions to recreate disability-defining models, it can be seen that many respondents still believe that people with disabilities should have special education and sheltered jobs. In particular, people with hearing and visual disabilities emphasised such a need. This indicates that despite adopting the social model, the respondents still see the need for separate spaces tailored to their needs and opportunities to learn and work with other people with disabilities. Thus, despite the belief that eliminating physical and cultural barriers will allow people with disabilities to be included in society, they are still attached to the current system that grew out of the medical model of defining disability.

TABLE 4. Impact of using social media on the subscribed disability model

\begin{tabular}{|c|c|c|c|c|}
\hline & & Average & Standard deviation & Pearson's $r$ \\
\hline \multirow{3}{*}{$\begin{array}{l}\text { Social } \\
\text { model }\end{array}$} & $\begin{array}{l}\text { All buildings should be accessible } \\
\text { to people with disabilities }\end{array}$ & 3.8 & 0.6 & \multirow{3}{*}{0.512} \\
\hline & $\begin{array}{l}\text { Disability is not an individual } \\
\text { problem, but a social one }\end{array}$ & 2.4 & 1.19 & \\
\hline & $\begin{array}{l}\text { Physical and cultural barriers are } \\
\text { the reason for excluding people } \\
\text { with disabilities }\end{array}$ & 3.5 & 0.8 & \\
\hline \multirow{3}{*}{$\begin{array}{l}\text { Medical } \\
\text { model }\end{array}$} & $\begin{array}{l}\text { Doctors and other medical } \\
\text { professionals know what is best } \\
\text { for people with disabilities }\end{array}$ & 2.1 & 1.3 & \multirow{3}{*}{0.213} \\
\hline & $\begin{array}{l}\text { People with disabilities require } \\
\text { special schools and sheltered jobs } \\
\text { to be created }\end{array}$ & 3.0 & 1.01 & \\
\hline & $\begin{array}{l}\text { People with disabilities should be } \\
\text { surrounded by compassion and } \\
\text { charity support }\end{array}$ & 2.8 & 0.9 & \\
\hline
\end{tabular}

Source: Results of own studies. $\mathrm{N}=346$.

The adopted disability model also translated into online activities. The respondents who used social media took action to change the situation of people with disabilities. The comparison of the Pearson correlation coefficient reveals a relationship between the use of social media and the respondents' adoption of roles. 
TABLE 5. Roles adopted by people who use social media during the Covid-19 pandemic

\begin{tabular}{|l|c|}
\hline \multicolumn{2}{|c|}{ Participation in Facebook groups } \\
\hline \multicolumn{2}{|c|}{} \\
\hline I have publicised examples of online discrimination & Pearson's $r$ \\
\hline I have participated in a political meeting & 0.73 \\
\hline I have participated in an online demonstration of protest & 0.25 \\
\hline I have signed an online petition & 0.24 \\
\hline $\begin{array}{l}\text { I have publicised good practices and successes of people } \\
\text { with disabilities online }\end{array}$ & 0.53 \\
\hline I have transferred money to aid and charity campaigns & 0.32 \\
\hline I have raised funds for my own needs & 0.43 \\
\hline I have asked for help to solve problems & 0.34 \\
\hline I have provided online help to people with disabilities & 0.77 \\
\hline $\begin{array}{l}\text { I have publicised online campaigns and protests organised by people } \\
\text { with disabilities }\end{array}$ & 0.52 \\
\hline I use online courses and education & 0.22 \\
\hline I buy on the Internet; I shop on the Internet & 0.48 \\
\hline I use public services, online banking and other services & 0.61 \\
\hline I am looking for help with my disability & 0.42 \\
\hline I work/study online & 0.31 \\
\hline
\end{tabular}

Source: Results of own studies. $\mathrm{N}=346$. The respondents answered yes/no/don't know to the questions. The answer "I don't know" was not taken into account in the analysis.

From the activities that focused on their own environment, the use of social media had a major impact on the activities carried out in the online space that involved showing good practices and successes of people with disabilities (Pearson's $r=0.53$ ) and publicising examples of discrimination (Pearson's $r=0.73$ ). Providing online help to people with disabilities was also dependent on the use of social media (Pearson's $r=0.77$ ). These results indicate a correlation between using social media for self-help activities and fighting for the rights of people with disabilities to have full and equal participation in social life. In addition, the respondents admitted that they were looking for support through social media. This is indicated by the average relationship between using the media and asking for advice (Pearson's $r=0.34$ ), raising funds to meet their needs (Pearson's $r=0.43$ ) and transferring money to others (Pearson's $r=0.32$ ). 
The data show that people's activity on social media also significantly affects the transfer of activities involved in improving the situation of people with disabilities outside the Internet. This is indicated by a Pearson coefficient of 0.586 for people who participated in demonstrations, and a weak relationship between the use of social media and participation in meetings of a political nature (Pearson's $r=0.33$ ).

People with disabilities also benefited from Internet activities that allowed them to be independent and self-reliant: using public services, online banking and other services (Pearson's $r=0.61$ ), shopping online (Pearson's $r=0.61$ ) and help in connection with their disability (Pearson's $r=0.43$ ).

\section{CONCLUSIONS}

During the Covid-19 pandemic, people with disabilities still feel that their lives do not depend on themselves, but on institutional and social conditions. This is probably the effect of the feeling that in the case of disease, quarantine for people with disabilities requires other people and institutions, influencing their constructed identities. The respondents indicated that disability is a feature that defines them, showing that they still treat their dysfunctions as an important element that affects both their self-esteem and their relations with society. This conclusion reinforces the respondents' recognition of the importance of creating spaces that are reserved for people with disabilities regarding education and the labour market. This indicates that although they generally reject the medical model for defining disability and instead subscribe to the social one, they are still attached to institutional solutions that are of an exclusive nature.

At the same time, however, it can be seen that social media perform a vital function in mobilising the disabled community. The respondents took political action and were engaged in the fight for their rights not only in the online space but offline as well. The respondents also publicised the successes of people with disabilities, organised fundraisers and participated in such fundraisers themselves via social media. The research results show that there is a relationship between using social media, providing assistance to people with disabilities and asking for help in solving problems.

The collected data show that activity on new media impacts the identities built by people with disabilities. It has the strongest effect on emancipatory and self-help activities by promoting active attitudes, which means that, by using social media, their identities change. They are more aware of their rights, which is why they more often choose the social model of disability and build positive 
identities. However, this is a slow process, and it requires observation and testing in subsequent years.

The fact that the change has taken place in role-playing allows for the formed identities to be modified. Transferring activity to the Internet, may exclude a large number of people with disabilities, who cannot use it. It may make them vulnerable to exclusion during the pandemic and have a negative impact on their role fulfilment and identity.

\section{BIBLIOGRAPHY}

Bowker Natilene, Keith Tuffin. 2003. "Dicing with deception: People with disabilities' strategies for managing safety and identity online". Journal of Computer-Mediated Communication 8(2). https://academic.oup.com/jcmc/article/8/2/JCMC827/4584284 [access: 15.02.2021].

Bowker Natilene, Keith Tuffin. 2002. "Disability discourses for online identities". Disability and Society 3(17): 327-344.

Braithwaite Dawn O., Vincent R. Waldron, Jerry Finn. 1999. "Communication of social support in computer-mediated groups for people with disabilities". Health Communication 11(2): 123-151.

Britt Lory, David R. Heise. 2000. From shame to pride in identity politics. In: Self, identity, and social movements, S. Stryker, T.J. Owens, R.W. White (eds.), 252-268. Minneapolis-London: University of Minnesota Press:

Burke Peter J. 2006. "Identity change". Social Psychology Quarterly 69(1): 81-96. doi.org/10.1177/019027250606900106.

Burke Peter J., Judy C. Tully. 1977. "The measuring of role identity”. Social Forces 55(4): 881-897.

Burke Peter J. 2009. Tożsamości a struktura społeczna: Wykład z okazji przyznania nagrody Cooleya-Meada w roku 2003. In: Nowe perspektywy teorii socjologicznej, A. Manterys, J. Mucha (eds.), 113-128. Kraków: Nomos

Czapiński Janusz, Tomasz Panek. 2015. Social Diagnosis 2015. Conditions and quality of life of Poles. http://www.diagnoza.com/ [access: 02.09.2019].

Darling Rosalyn B. 2003. "Toward a model of changing disability identities: A proposed typology and research agenda". Disability and Society 18(7): 881-895. doi.org/10.1080/0968759 032000127308 .

Darling Rosalyn B. 2013. Disability and identity: Negotiating self in a changing society. Boulder, Colorado: Lynne Rienner Publishers.

Darling Rosalyn B., Alex D. Heckert. 2010a. "Orientations toward disability: Differences over the lifecourse". International Journal of Disability, Development and Education 57(2): 131-143. doi.org/10.1080/10349121003750489.

Darling Rosalyn B., Alex D. Heckert. 2010b. Activism, models, identities, and opportunities: A preliminary test of a typology of disability orientations. In: Disability as a Fluid State. Research in Social Science and Disability, S.N. Barnartt, B.M. Altman (eds.), 203-229. Howard House: Emerald Group Publishing Limited. 
Diagnoza społeczna. 2015. Bazy. http:/www.diagnoza.com/Indywidualni respondenci.sav [access: 1.09.2021].

Dunn Dana S., Shane Burcaw. 2013. "Disability identity: Exploring narrative accounts of disability”. Rehabilitation Psychology 58(2): 148-157. doi:10.1037/a0031691.

Ellis Katie, Gerard Goggin. 2015. "Disability media participation: Opportunities, obstacles and politics media international". Australia incorporating Culture and Policy 154(1): 78-88. doi.org/10.1177/1329878X1515400111.

Elis Katie, Mike Kent. 2011. Disability and new media. New York: Routledge.

Forber-Pratt Anjali J., Dominique A. Lyew, Carlyn Mueller, Leah B. Samples. 2017. "Disability identity development: A systematic review of the literature". Rehabilitation Psychology 62(2): 198-207. doi.org/10.1037/rep0000134.

French Sally, John Swain. 2012. Working with disabled people in policy and practice. London: Palgrave Macmillan.

Gill Carol J. 1997. "Four types of integration in disability identity development". Journal of Vocational Rehabilitation 9(1): 39-46. doi:10.3233/JVR-1997-9106.

Goggin Gerard, Christopher Newell. 2006. "Editorial comment: Disability, identity, and interdependence: ICTs and new social forms, Information". Communication and Society 9(3): 309-311. doi: 10.1080/13691180600751272.

Goggin Gerard, Christopher Newell. 2003. Digital disability: The social construction of disability in new media. Maryland: Rowman and Littlefield.

Goggin Gerard. 2015. "Communication rights and disability online: Policy and technology after the World Summit on the Information Society". Information, Communication and Society December, 3(18): 327-341.

Guibernau Montserrat. 2013. Belonging. Solidarity and division in modern societies. Cambridge: Polity Press.

Gustavsson Anders, and Catarina Nyberg. 2015. "I am different, but I'm like everyone else": The dynamics of disability identity. In: Childhood and disability in the Nordic countries. Being, becoming, belonging, R. Traustadóttir, B. Ytterhus, S. Egilson, B. Berg (eds.), 69-84. New York: Palgrave MacMillan.

Hahn Harlan D., Belt Todd L. 2004. "Disability identity and attitudes toward cure in a sample of disabled activists". Journal of Health and Social Behavior 45(4): 453-464. doi.org/10.1177/002214650404500407.

Haller Beth. 2010. Representing disability in an ableist world: Essays on mass media. Louisville: Avocado Press.

Henderson Alison, Rachel Bowley. 2010. "Authentic dialogue? The role of «friendship» in a social media recruitment campaign". Journal of Communication Management 14 (3): 237-257. doi.org/10.1037/a0031691.

Johnson Liz, Eileen Moxon. 1998. "In whose service? Technology, care and disabled people: The case for a disability politics perspective". Disability And Society 13(2): 241-258. doi.org/10.1080/09687599826812.

Kampert Amy, Anthony J. Goreczny. 2007. "Community involvement and socialization among individuals with mental retardation". Research in Developmental Disabilities 28(3): 278-286. doi: 10.1016/j.ridd.2005.09.004.

Lupton Deborah, Wendy Seymour. 2000. “Technology, selfhood and physical disability". Social Science and Medicine 50(12): 1851-1862. doi.org/10.1016/S0277-9536(99)00422-0. 
Masłyk Tomasz, Ewa Migaczewska, Maria Stojkow, Dorota Żuchowska-Skiba. 2016. Aktywni niepetnosprawni? Obywatelski i społeczny potencjat środowiska osób niepetnosprawnych. Kraków: Wydawnictwa AGH.

Morris Jenny. 2001. "That kind of life? Social exclusion and young disabled people with high levels of support needs". Critical Social Policy 21(2):161-183. doi: 10.1177/026101830102100202.

Poppen William, Natalie Bradley. 2003. "Assistive technology, computers and Internet may decrease sense of isolation for homebound elderly and disabled persons". Technology and Disability 15(1): 19-25. doi: 10.3233/TAD-2003-15104.

Putnam Michelle. 2005. "Developing a framework for political disability identity". Journal of Disability Policy Studies 16(3), 188-199. doi: 10.1177/10442073050160030601.

Seymour Wendy, Deborah Lupton. 2004. Holding the line online: Exploring wired relationships for people with disabilities. Disability and Society 19 (4): 291-305. doi: 10.1080/09687590410001689421.

Shakespeare Tom. 1996. Disability, identity and difference. In: Exploring the Divide, C. Barnes, G. Mercer (eds.), 94-113. Leeds: The Disability Press.

Shpigelman Carmit-Noa, Carol J. Gill. 2014. "Facebook use by persons with disabilities". Journal of Computer-Mediated Communication 19(3): 610-624. doi.org/10.1111/jcc4.12059.

Stojkow Maria, Dorota Żuchowska-Skiba. 2014. „W kierunku nowej tożsamości - osoby niepełnosprawne w drodze ku emancypacji”. Studia Socjologiczne 213(2): 153-174.

Stryker Sheldon. 2000. "Identity competition: Key to differential social movement participation?”. In: Self, identity, and social movements, S. Stryker, T.J. Owens, R.W. White (eds.), 21-40. Minneapolis: University of Minnesota Press.

Stryker Sheldon, Peter J. Burke. 2000. "The past, present, and future of an identity theory". Social Psychology Quarterly 63(4): 284-297. doi: 10.2307/2695840.

Swain John, Sally French. 2000. "Towards an affirmation model of disability". Disability and Society 15(4): 569-582. doi.org/10.1080/09687590050058189.

Thomas Carol. 2004. "How is disability understood? An examination of sociological approaches". Disability and Society 19(6): 569-583. doi.org/10.1080/0968759042000252506.

Thoreau Estelle. 2006. "Ouch! An examination of the self-representation of disabled people on the Internet". Journal of Computer-Mediated Communication 11(2): 442-468. https://doi. org/10.1111/j.1083-6101.2006.00021.x.

Walsh Michael, Roisin Cormack, Malcolm MacLachlan. 2020. Digital and assistive technology use in disability services during Covid-19: A report on the experiences of 120 service providers "Right to Connect". National Clinical Programme for People with Disability. https:// www.hse.ie/eng/about/who/cspd/ncps/disability/programme-publications /digital-and-assistive-technology-use-in-disability-services-during-covid19-report.pdf [access: 15.02.2021].

Wright Kevin B., Sally B. Bell. 2003. "Health-related support groups on the Internet: Linking empirical findings to social support and computer-mediated communication theory". Journal of Health Psychology 8(1): 39-57. doi: 10.1177/1359105303008001429.

Zaagsma Miriam, Karin M. Volkers, Eline A. K. Swart, Alice P. Schippers, Geert Van Hove. 2020. "The use of online support by people with intellectual disabilities living independently during COVID-19". Journal of Intellectual Disability Research 64: 750-756. https://doi. org/10.1111/jir.12770.

Żuchowska-Skiba Dorota. 2018. „Integracja, emancypacja czy afirmacja? Tożsamości osób z niepełnosprawnościami we współczesnej Polsce”. Przegląd Socjologii Jakościowej 14(3): 12-28. doi.org/10.18778/1733-8069.14.3.02. 
Żuchowska-Skiba Dorota. 2018. Niepełnosprawność w dobie Web 2.0. Znaczenie portali społecznościowych dla osób z niepełnosprawnościami. In: Wybrane problemy społeczne Teraźniejszość - Przyszłość, E. Grudziewska, M. Mikołajczyk (eds.), 138-148. Warszawa: Wydawnictwo Akademii Pedagogiki Specjalnej.

Dorota Żuchowska-Skiba

\section{SPOLECZNY WYMIAR INTERNETU Z PERSPEKTYWY OSÓB Z NIEPELNOSPRAWNOŚCIAMI W CZASIE PANDEMII COVID-19}

\section{Streszczenie}

Dla ludzi, nie tylko osób z niepełnosprawnościami, sieć internetowa w dobie epidemii Covid-19 stanowi przestrzeń życiową, w której mogą realizować swoje potrzeby społeczne w czasie obowiązkowej izolacji społecznej. Dotychczasowe badania pokazują że portale społecznościowe mają ogromny potencjał w zakresie budowania i wzmacniania relacji społecznych, tworzą przestrzeń umożliwiającą osobom z niepełnosprawnościami udział w debacie na tematy ważne dla tej kategorii społecznej oraz walkę o swoje prawa. Stymulują również kształtowanie się poczucia przynależności do społeczności, co buduje swoistą więź i solidarność wśród osób z niepełnosprawnościami. W tym sensie Internet stanowi ważną przestrzeń, sprzyjającą kształtowaniu tożsamości osób z niepełnosprawnościami. Głównym celem artykułu jest ukazanie relacji pomiędzy używaniem mediów społecznościowych a elementami konstytuującymi tożsamości osób z niepełnosprawnościami oraz ukazanie aktywności o charakterze społecznym i przyjmowanych ról w przestrzeni Internetu. W badaniu przeprowadzonym online wzięło udział 346 osób aktywnych na profilach dla osób z niepełnosprawnościami.

Słowa kluczowe: tożsamość niepełnosprawności, media społecznościowe, wirtualne społeczności, pandemia Covid-19, społeczne relacje 